\title{
Gastric cancer screening using the serum pepsinogen test method
}

\author{
KaZumasa Miki
}

Division of Gastroenterology and Hepatology, Department of Internal Medicine (Ohmori), School of Medicine, Faculty of Medicine, Toho University, 6-11-1 Ohmori Nishi, Ohta-ku, Tokyo, 143-8541 Japan

\begin{abstract}
The current status of gastric cancer screening, worldwide, as well as in Japan, using the serum pepsinogen test method, was reviewed. We performed a metaanalysis of sensitivity and specificity results from 42 individual studies (27 populationbased screening studies: $n=296553$ and 15 selected groups: $n$ = 4 385). Pooled pairs of sensitivity and false-positive rates (FPr) for pepsinogen I level $\leq 70 \mathrm{ng} / \mathrm{ml}$; pepsinogen $\mathrm{I} / \mathrm{II}$ ratio $\leq$ 3 , had a sensitivity of $77 \% / \mathrm{FPr} 27 \%$. The positive predictive value varied between $0.77 \%$ and $1.25 \%$, and the negative predictive value varied between $99.08 \%$ and $99.90 \%$. Therefore, we concluded that the definition of the pepsinogen test should include the pepsinogen I/II ratio, as consistency was obtained for both the population-based studies and the selected groups for those studies that used pepsinogen I serum levels together with the pepsinogen I/II ratio for screening for gastric cancer in high-incidence regions other than Japan. Individuals testing positive for extensive atrophic gastritis by serum pepsinogen levels undergo endoscopic examination to test for the presence of gastric cancer. We should increase the efficacy and cost-effectiveness of the gastric cancer screening system, by the identification of groups, at low-risk, as well as those at high-risk, of developing gastric cancer, using a combination of assays of serum Helicobacter pylori antibody titers and the concentration of pepsinogen I and II. In conclusion, the pepsinogen test method can be used as a screening test for high-risk subjects, rather than as a tool for screening for cancer itself. I hope that this pepsinogen test method will become a world standard for gastric cancer prevention in the near future, in other countries, as well as in Japan.
\end{abstract}

Key words Gastric cancer · Cancer screening · High-risk group - Serum pepsinogen · Helicobacter pylori antibody

Offprint requests to: $\mathrm{K}$. Miki

Received: January 16, 2006 / Accepted: August 15, 2006

\section{Introduction}

Gastric cancer remains one of the leading causes of cancer-related death worldwide [1]. The highest rates of gastric cancer are in Costa Rica, Chile, and Japan; one of the lowest rates is in the United States. In Japan, a gastric cancer screening program was introduced in the 1960s as a public health service and this has gradually been extended to include the whole nation. Currently, screening is performed throughout the country, and more than 6 million people annually undergo screening provided by either a community service or in the workplace. As a result, thousands of stomach cancer cases are detected each year, and the cancer screening has greatly contributed to a reduction in gastric cancer mortality rates [2,3]. Screening most frequently includes the use of double-contrast barium $\mathrm{X}$-rays or panendoscopy, as well as photofluorography. Recently, serum pepsinogen tests were introduced for mass screening to identify individuals at high risk for gastric cancer. Individuals testing positive for extensive atrophic gastritis, based on their serum pepsinogen levels, undergo endoscopic examination to test for the presence of gastric cancer. The results of the serum pepsinogen screening tests are comparable and, in some respects superior to, those of traditional screening [4-7]. The objective of this review is to describe the current status of gastric cancer screening, using the serum pepsinogen test method, worldwide, as well as in Japan.

Gastric cancer, despite a recent decline in its incidence, is still the second leading cause of cancer deaths in Japan. For this reason, much effort has been directed to the early detection of cancer, using mass screening programs throughout the country. At present, as described above, about 6 million people are screened annually, by photofluorography; however, the sensitivity of this method is by no means high if endoscopy is used as a yardstick $[4,7,8]$. In contrast, the measurement of 
serum pepsinogens has recently gained attention as a new screening test for gastric cancer [4-12]. This method is particularly attractive given its lower cost and simplicity to administer relative to photofluorography $[4,7-9,12,13]$.

\section{Serum pepsinogen}

Serum pepsinogen consists of two biochemically and immunologically distinct types, namely, pepsinogen I (PGI) and pepsinogen II (PGII) (PGI is also called PG "A", and PGII is also called PG"C"). PGI is produced by chief and mucous neck cells in the fundic glands, while PGII is produced by these cells and also by cells in the pyloric glands and Brunner's glands [1,1416]. It is widely accepted that serum pepsinogen levels reflect the functional and morphologic status of the gastric mucosa. As the fundic gland mucosa is reduced, PGI levels gradually decrease, whereas PGII levels remain fairly constant $[4,6]$. As a result, a stepwise reduction of the PGI/II ratio is closely correlated with the progression from normal gastric mucosa to extensive atrophic gastritis; this ratio of more than 3 has a sensitivity of $93.3 \%$ and specificity of $87.7 \%$ for the diagnosis of normal fundic gland mucosa $[4,6]$.

\section{Pepsinogen test method}

It is generally accepted that serum pepsinogen concentrations are related to gastritis, and gastric mucosal lesions, with a particular relationship to chronic atrophic gastritis (CAG) [4,5,17-19]. At least for intestinal-type [20] gastric carcinoma, CAG is considered to be a preceding condition in the sequential histopathological changes that lead to cancer [21-23]. Pepsinogen has therefore been used as a serological biopsy for more than 20 years in different countries and different sets of patients [24-33].

Generalized screening as it is practiced in Japan may not be feasible in other countries. Owing to its low positive predictive value, some authors [34] have reported their concern about the effectiveness and applicability of the pepsinogen test for gastric cancer screening in countries with a lower prevalence of gastric cancer than that in Japan. Furthermore, significant differences in methodologies may prejudice the assessment of consistency. For instance, different cutoff values are used for the definition of positivity; either pepsinogen I levels [28,35-37] or both pepsinogen I and II [14-16] are considered; and not all studies have considered other factors, such as sex, age, and smoking and drinking habits, and Helicobacter pylori infection, factors which are said to influence pepsinogen levels.
Nevertheless, as a noninvasive test, pepsinogen screening deserves further evaluation.

Based on the assessment of consistency of diagnostic validity among studies, we first aimed to evaluate the use of pepsinogen as a screening for gastric cancer in terms of the best methodology (pepsinogen I alone, or pepsinogen I and II), and with regard to the best cutoff point. We also aimed to define the usefulness of pepsinogen tests for identifying individuals with CAG and other associated lesions; namely, intestinal metaplasia and low-grade dysplasia, as in most Western countries the strategies for an early diagnosis of gastric cancer have been focusing on follow-up protocols for these individuals. It is generally accepted that following up these lesions is required for an early diagnosis of gastric cancer [38].

\section{Review of the literature: pepsinogen test for gastric cancer screening}

We performed a metaanalysis of sensitivity and specificity results from individual reports on the use of pepsinogen tests. An intrinsic cutoff effect was assumed, and a random-effect model was used for pooling, as reported previously [39]. After defining the search strategy (see "inclusion criteria" below), published articles on pepsinogen test validity were found, using a computer-aided search in the Medline database (PubMed) and data reports from Japan.

Articles in any language were considered. Quality criteria for the inclusion of a study were defined as follows:

1. Clear definition of the study population and of available data on variables such as age, sex, smoking or alcohol habits, and Helicobacter pylori infection had to be noted.

2. Only those studies in which gastric endoscopic examination (with biopsies) was performed as a reference test or gold standard were considered. Two different results were considered: diagnosis of gastric cancer; and diagnosis of lesions associated with gastric cancer, such as atrophy or dysplasia. It was assumed that, as diagnosis is based on histology, definitions had not changed since the time during which the studies took place, and it was also assumed that there were no differences between definitions used by Japanese and Western pathologists. Also, "adenoma" was considered to be a synonym of low-grade dysplasia. Of note, a discussion of histopathological classifications is beyond the scope of this text.

3. Radioimmunoassay $[36,40,41]$ and enzyme immunoassay $[42,43]$ were acceptable as methods for 
pepsinogen test definition, as long as results were expressed in nanograms per milliliter $(\mathrm{ng} / \mathrm{ml})$ or the equivalent. A pepsinogen test was defined as the measurement of at least pepsinogen I, but ideally of both pepsinogens, and thus the measurment of the pepsinogen I/II ratio. All cutoffs for positivity were considered as long as they were clearly defined or easily determined from the "methods" or "results" sections of the study.

Studies that were not related to the clinical use of pepsinogen for the diagnosis of gastric cancer and which did not contain any data on pepsinogen levels and their variation in relation to gastric lesions were excluded.

A standardized data extraction form was used, after a short period of pilot use by two reviewers. Agreement was obtained on data and studies to be included, and on those data to exclude or not to consider for statistical analysis.

Further assessment of heterogeneity was estimated by using a chi-square test with Meta-DiSc for Windows (version 1.0.9; XI Cochrane Colloquium, Barcelona, Spain). A random-effect model was used for pooling sensitivity, specificity, and the estimated diagnostic odds ratio (DOR), by addressing both within-study sampling error and variation between studies. We assumed an implicit cutoff effect; thus, we considered diagnosis (cancer or precancerous) and the best cutoff after pooling for each outcome.

The time range of the pepsinogen search was from 1982 to 2002.

Forty-two data sets $[4,5,11,12,18,44-81]$ were included: $27(64 \%)$ population-based screening studies $(n=296553)$ and $15(36 \%)$ selected groups $(n=4385)$. Measurement of serum pepsinogen concentration was carried out using either radioimmunoassay $[40,41]$ or enzyme immunoassay $[30,42,43]$. Homogeneous sensitivity and DOR estimates were found in studies using both pepsinogen I levels and pepsinogen I/II ratio calculations. Pooled pairs of sensitivity and false-positive rates (FPr) for pepsinogen $\mathrm{I} \leq 70 \mathrm{ng} / \mathrm{ml}$; pepsinogen $\mathrm{I} / \mathrm{II}$ ratio $\leq 3$, pepsinogen $\mathrm{I} \leq 50 \mathrm{ng} / \mathrm{ml}$; pepsinogen $\mathrm{I} / \mathrm{II}$ ratio $\leq 3$, and pepsinogen $\mathrm{I} \leq 30 \mathrm{ng} / \mathrm{ml}$; pepsinogen $\mathrm{I} / \mathrm{II}$ ratio $\leq$ 2 , had sensitivities of $77 \% / \mathrm{FPr} 27 \%, 68 \% / \mathrm{FPr} 31 \%$, and $52 \% / \mathrm{FPr} 16 \%$, respectively. The positive predictive value (PPV) varied between $0.77 \%$ and $1.25 \%$, and the negative predictive value (NPV) varied between $99.08 \%$ and $99.90 \%$. In selected groups, pooling was possible only when considering pepsinogen $\mathrm{I} \leq 70 \mathrm{ng} / \mathrm{ml}$; pepsinogen I/II ratio $\leq 3$ : giving sensitivity, $57 \%$; specificity, $80 \%$; PPV , 15\%; and NPV, $83 \%$. As for the diagnosis of dysplasia, studies considering pepsinogen $\mathrm{I} \leq$ $50 \mathrm{ng} / \mathrm{ml}$; pepsinogen I/II ratio $\leq 3$ obtained a sensitivity of $65 \%$ and specificities ranging from $74 \%$ to $85 \%$, both with NPV $>95 \%$. We concluded that the definition of the pepsinogen test should include the pepsinogen I/II ratio, as consistency was obtained with this ratio, both in population-based studies and in selected groups for those studies that used pepsinogen I serum levels together with the pepsinogen I/II ratio for screening for gastric cancer in high-incidence regions other than Japan. Further studies of this test in the management of high-risk patients seem to be warranted [39].

A diagnostic test should be reproducible and valid; those tests with a screening purpose, in particular, should be free of discomfort or risk. For the gastrointestinal tract, direct visualization through endoscopic examination is probably the best method for the diagnosis of most protruding and depressed cancer lesions. It easily allows the collection of mucosal specimens for histopathological evaluation, although very high interobserver variability and sampling errors exist for flat lesions and changes, including gastric atrophy, intestinal metaplasia, and even dysplasia. But endoscopic examination is invasive, not patient-friendly, and is not always easily accessible. Furthermore, screeening tests should be economical. Ohata, based on the results of the 2001 annual report of gastric cancer screening prepared by the Japanese Association of Gastrointestinal Mass Screening in 2002, reported that initial screening with conventional barium X-ray cost 3500 yen per subject, and endoscopy cost 13000 yen per subject. The total cost for the screening program was estimated as 25393209000 yen per year. The cost required to find a single case of gastric cancer can be estimated as 4408543 yen, whereas, using the pepsinogen test alone, the cost decreased to 2275387 yen [13]. Therefore, the selection of individuals for endoscopic examination according to the results of noninvasive tests (for instance, the use of the fecal occult blood test [FOBT] for colon and rectum neoplasias) seems to be attractive for most screening programs.

\section{When should pepsinogens be measured?}

Pepsinogen levels in blood seem to be related to functional changes in the stomach, and their use as serological biopsy has been reported for over 20 years $[17,18,71,74]$. We focused mainly on the diagnosis of atrophy, as its relation with gastric cancer has been reported. In most Western countries, the focus was on the identification of individuals for intervention studies, whereas in Japan the use of pepsinogen levels was meant to identify those for endoscopic examination, and those at risk for gastric cancer. It is not surprising that studies with different purposes tend to use different methodologies.

Some questions remain unanswered; namely, the consistency of the pepsinogen test in several countries and 
population sets, and the definition of the optimal cutoff. It is always ambitious to consider a metaanalysis, because even if all articles are tracked, publication bias is always troublesome. Furthermore, with the previously stated heterogeneity of methods, it is almost an impossible task, and probably for that reason no metaanalysis has been performed before now on the validity of the pepsinogen test for identifying gastric cancer or premalignant gastric lesions. We decided to evaluate the results of several studies and reports, focusing our search mainly on reports from different countries and reports with different purposes (screening or follow-up). We considered addressing the reproducibility of the pepsinogen test by using sensitivity and specificity measures, as these measures show little variation with the prevalence of the disease. Assuming that cutoff points have an intrinsic effect on test validity, we first aimed to assess consistency according to the different cutoff levels used, and then we aimed to pool and define the best discriminatory value for the diagnosis of cancer or other lesions, if possible.

\section{Factors affecting pepsinogen levels}

Globally, low PPVs were found in population studies. To overcome this problem, some authors tried to adjust cutoff or modify strategies $[55,74,75]$ by measuring confounding factors known to influence pepsinogen levels in blood. From our analysis we were only able to find out that the pepsinogen I/II ratio tended to decrease with age and with the presence of $H$. pylori, but it was not possible to define any modification on cutoff. There were no conclusions in relation to other factors, such as sex or smoking and drinking habits. Age seems to be related to an increase in acid secretion in humans [76]; however, the decrease in pepsinogen I level and the pepsinogen I/II ratio found in most studies may be related not to age but to atrophic changes diagnosed from these findings. The presence of $H$. pylori, assessed either by serological evaluation or by immunohistochemistry in biopsy specimens, in conjunction with inflammation, seems to increase pepsinogen I and II levels and to decrease the pepsinogen I/II ratio [77-79]. Furthermore, as IgG may persist for several years after the disappearance of $H$. pylori infection, its measurement in high-incidence countries may not be effective for diagnosis, as no information is gained. Some authors consider that the value for $H$. pylori negativity is more important. That is, in high-prevalence countries, it may be more important to diagnose an individual with gastric atrophy or other changes as negative for H. pylori; this finding could mean that a long time had passed since infection and that mucosal changes had occurred, thus representing a great risk of cancer [13,82-84].
According to our review, around 600 individuals should be screened, using the pepsinogen test, to diagnose one gastric cancer in Japan $[13,85,86]$. Considering that the main drawback is the positive rate (around $20 \%$ ), this strategy has to be available at a low price, as it is in Japan (at present, the cost of measuring both pepsinogen I and II can be covered by 1000 yen, which is less than US $\$ 10$ at current exchange rates). It could be an attractive strategy, as $75 \%$ of all gastric cancers discovered in these studies $[13,85,86]$ were early gastric cancers (EGCs) $[6,11,80,85]$, of curable forms with almost $100 \%$ 5-year survival. It was possible to evaluate the best strategy for screening as the use of pepsinogen $\mathrm{I}<70 \mathrm{ng} / \mathrm{ml}$; pepsinogen I/II ratio $<3$. Pooled sensitivity for these values $[13,85,86]$ was $77.3 \%$ and specificity, $73.2 \%$. Studies using only pepsinogen I obtained heterogeneous results, even considering obvious differences after cutoff, probably related to other factors, as discussed above. Only the pepsinogen I $<30 \mathrm{ng} / \mathrm{ml}$; pepsinogen $\mathrm{I} / \mathrm{II}$ ratio $<2$ criteria, and not the pepsinogen I $<50 \mathrm{ng} / \mathrm{ml}$; pepsinogen I/II ratio $<3$ showed a significant increase in specificity $(84 \%)$ compared to the pepsinogen I $<70 \mathrm{ng} / \mathrm{ml}$; pepsinogen I/II ratio $<3$ criteria.

We also noted very high NPVs in all studies, which did not differ between the population-based studies and the selected group studies $(99.9 \%$ and $80 \%$, respectively), even considering expected differences in prevalence. This could be the rationale for using the pepsinogen test under follow-up scenarios. As stated above, endoscopy shows low inter-observer agreement as far as neoplastic and non-neoplastic flat lesions are concerned. The use of a noninvasive test; simultaneous measurements of pepsinogen I and II, which reflect all variations in gastric mucosal status, may be able to allow the allocation of some patients, who would otherwise undergo several, eventually inefficacious examinations, to a less intensive follow-up scheme. Screening in Japan has already used this strategy, as a further pepsinogen assay is proposed only 5 years after a negative result in any individual $[29,86]$. Although no study has specifically analyzed the relationship between the decline of the pepsinogen I/II ratio and the risk of gastric cancer [81], it was noted that variations in the pepsinogen I/II ratio were thought to reflect mainly the advance of atrophy. Other authors [71] showed that a mean pepsinogen I/II ratio of gastric cancer was lower than that for CAG, for dysplasia, and for intestinal metaplasia. In Western countries, where gastric cancer has been declining, these results may be more attractive for early diagnosis strategies, focusing on the follow-up of patients with precancerous lesions. Unfortunately, we were not able to assess and define the best cutoff for this purpose; this inability to define the best cutoff may be related to various factors: the low inter-observer agreement in the endoscopic assessment of atrophy, the biopsy protocol 
and sample error, and even differences among pathologists. We can speculate that the cutoff should be the same as the one used for the diagnosis of gastric cancer, as, in fact, the intention is to measure functional changes after atrophy. The highest specificity and NPV were noted when the cutoff pepsinogen I $<30 \mathrm{ng} / \mathrm{ml}$; pepsinogen I/II ratio $<2$ was used. As most follow-up programs may be endoscopy-based, the most important factor is to accurately diagnose the absence of disease or severe lesions.

To conclude this section, the use of the same cutoff for positivity of the pepsinogen test obtained similar and comparable results in different sets of individuals and in different countries, both for the diagnosis of such neoplastic gastric lesions as dysplasia and for the diagnosis of carcinoma, a finding that attests to the consistency of the test. Thus, if the pepsinogen test could be made available at a reasonable cost for a screening scenario in high-incidence regions other than in Japan, and for the management of high-risk patients, studies to assess the efficacy and the validity of the test would seem to be worthwhile, as no other noninvasive test has revealed better results to date.

The definition of the pepsinogen test should include the pepsinogen I/II ratio, as homogeneity was obtained both in population-based studies and in selected groups for those studies that used pepsinogen I serum levels together with the pepsinogen I/II ratio. For gastric cancer screening in high-incidence regions other than Japan, and for the management of high-risk patients, further studies using this test would seem to be worthwhile, as stated before.

\section{Usefulness of gastric cancer screening using the serum pepsinogen test method}

To compare the accuracy of the two screening methods - X-ray and pepsinogen test - and to elucidate the usefulness of the serum pepsinogen test method, we performed a study in Toyama Prefecture, which is located in the northern part of Japan [7]. Its total population is about 1000000 , with a registered gastric cancer death rate, in 1998, of 70.7/100000 in men and 39.3/ 100000 in women. These figures are higher than the mean gastric cancer death rates for the whole country in 1998 (men, 53.6/100000; women, 27.6/100000).

This study was specifically designed for the screening of a high-risk gastric cancer group, using the both the Xray and pepsinogen test methods simultaneously in the same study subjects. They had lived in the same district during the study period, and the incidence (i.e., sensitivity) of detected gastric cancer cases and the PPV were comparable for the two methods, using endoscopy as a yardstick. These results suggest to us that the pepsino- gen test method is superior to the conventional X-ray method, although the results of the former may have overestimated the detection of gastric cancer compared with the latter, because the pepsinogen test method was conducted as prevalent screening while the X-ray method was done as incidental screening [87]. To date, few studies have directly examined whether the pepsinogen test method reduced gastric cancer mortality, except for a study in Adachi City in Tokyo and Kake City in Hiroshima Prefecture of Japan [88].

The single use of the pepsinogen test is by no means sufficient for gastric cancer screening; however, it provides a valuable measure for selecting the population that needs further screening with endoscopy $[4,18]$. As described above, the serum pepsinogen test was introduced for cancer screening to identify individuals with extensive atrophic gastritis [5]. Individuals testing positive for extensive atrophic gastritis by serum pepsinogen levels (pepsinogen I $\leq 70 \mathrm{ng} / \mathrm{ml}$, pepsinogen I/II ratio $\leq 3.0$ ) undergo endoscopic examination to test for the presence of gastric cancer. These test cutoff values have shown a sensitivity of $80 \%$, specificity of $70 \%$, cancer detection rate of $0.44 \%$, and a PPV of $1.5 \%$, using endoscopy as a yardstick [86]. In the past 10 years, a considerable number of screening services provided by workplaces and also by community health services have adopted the pepsinogen serum tests as a primary screening tool [86]. The results of these screenings demonstrate that the cancer detection rate of the screening with the serum tests is superior to and more costeffective $[5-7,12,13,86]$ than the conventional barium Xray mass screening. Furthermore, the percentage of early cancers detected by the new serum test screening is higher than that detected by conventional screening, and a considerable number of patients with these early cancers have been successfully treated by endoscopic surgery $[11,12,85]$. Because the tests detect extensive atrophic gastritis coexisting with cancer, it is possible that the diffuse (poorly differentiated) type [20] of cancer would not be detected by the serum tests. The results of the mass screenings, however, clearly indicate that this is not true, although the serum test screening is especially useful in detecting small asymptomatic cancers, nonulcerated morphology type, and welldifferentiated histology type $[6,7,11,45,86]$. Small asymptomatic cancers of these types are relatively difficult to detect using barium X-rays, whereas conventional screening is good for detecting cancers with an ulcerated morphology type and those with a poorly differentiated histology type, as well as advanced cases, which are frequently symptomatic. Because the cancers detected by the two screening methods are different, the combination of the two screening methods has greatly improved the screening efficacy and is more cost-effective than either method alone $[6,7,13,45,86]$. 
Recently, Ohata et al [13] showed a small overlap between the cancers detected by the pepsinogen test and those detected by X-ray screening. We have already recommended several strategies, including concurrent and serial combinations of serum pepsinogen measurement and photofluorography, as well as the single pepsinogen test method $[6,7,13,45,86]$.

In any particular mass screening area, we have to select the best screening system, depending on each individual case, according to the prevalence of gastric cancer, especially in the early stages $[45,86]$. Although gastric cancer cells are found to produce pepsinogen II more often than pepsinogen I [14-16], elevated pepsinogen values in serum are extremely rare, and only one case has ever been reported in such patients [89], because the amount of pepsinogens which are produced by gastric cancer cells is too small compared to the amount of pepsinogen I and II which are normally secreted into gastric lumen and only $1 \%$ of the amount secreted enters the circulation.

\section{Advantages of the pepsinogen test method}

The pepsinogen test method has many advantages compared to the X-ray method. That is, it is more sensitive. It is easy to carry out and patients do not feel much discomfort. There is no radiation exposure, and there are no side effects experienced from barium ingestion. This method is less expensive, it is fast, and many serum samples can be analyzed simultaneously $[6,9,12]$.

\section{Pepsinogen test kits now available in Japan}

Fifteen kinds of pepsinogen test kits, launched by 12 companies, are now available in Japan (Table 1). The pepsinogen test kits are convenient to use and can be used by ancillary medical staff for the measurement of human serum samples, as well as for urine, ascites, and tissue extracts. Therefore, it seems to us that the pepsinogen test method has a promising future.

\section{Validity of Helicobacter pylori antibody titer for gastric cancer screening}

In Japan, H. pylori infection and other unknown exposure factors may have played an important role in the development of chronic atrophic gastritis [24]. In Japan, $H$. pylori infection is associated with a significantly increased risk of atrophic gastritis [90,91] and the development of gastric cancer, especially early gastric cancer, by providing a suitable environment for carcinogenesis of the gastric mucosa, such as gastric atrophy and intestinal metaplasia $[36,92,93]$. Extensive atrophy may cause a loss of $H$. pylori infection, with a consequent reduction in the antibody titer. In addition, in advanced gastric cancer, lower antibody titers may be partly attributable to a diminished immune response [82].

\section{Gastric cancer screening strategy in the near future}

In the near future, we should increase the efficacy and cost-effectiveness of gastric cancer screening systems, by the identification of populations at low risk $[7,13,83,84,88]$, as well as those at high risk, of developing gastric cancer. For this purpose, combination assays of the serum $H$. pylori antibody titer and the concentrations of pepsinogen I and II should be used. Both serum measurement and H. pylori / CagA assays [46,68,88,9496] may be beneficial in serological screening strategies,

Table 1. List of manufacturers of pepsinogen test kits available in Japan

\begin{tabular}{lll}
\hline Manufacturer & Assay System & Year launched \\
\hline Dainabot Co., Ltd. (Abbott Japan Co., Ltd. Tokyo) & IRMA, CLIA & 1992,2000 \\
Wako Pure Chemical Industries, Ltd. Osaka & EIA, CLEIA & 1997,2000 \\
Eiken Chemical Co., Ltd. Tokyo & EIA, CLEIA & 1997,2000 \\
International Reagents Corporation. Kobe & EIA & 1997 \\
Sanwa Kagaku Kenkyusho Co., Ltd. Nagoya & LIA & 1999 \\
Kainos Laboratories, Inc. Tokyo & EIA & 1999 \\
Azwell Inc. Osaka & ELISA & 2000 \\
Kyokuto Pharmaceutical Industrial Co., Ltd. Tokyo & LIA & 2000 \\
Iatron Laboratories, Inc. (Mitsubishi Kagaku Iatron, Inc. Tokyo) & ELISA & 2000 \\
Kyowa Medex Co., Ltd. Tokyo & LIA & 2001 \\
Shima Laboratories Co., Ltd. Tokyo & EIA & 2002 \\
Fujirebio Inc. Tokyo & & 2005
\end{tabular}

IRMA, immunoradiometric assay; CLIA, chemiluminescent immunoassay; EIA, enzyme immunoassay; CLEIA, chemiluminescent enzyme immunoassay; LIA, latex immunoassay; ELISA, enzyme-linked immunoassay 
but cohort studies, evaluating these tests for screening purposes, need to be done.

\section{Conclusion}

In conclusion, the pepsinogen test method can be used as a screening test for high-risk subjects with atrophic gastritis, rather than as a tool for screening for cancer itself. Systematic endoscopic surveillance of this high-risk group is also useful. These strategies would require empirical assessment, using mortality as an endpoint. The international collaboration of health professionals should be encouraged to further advance the prevention and control of this global epidemic. We hope that the new serum pepsinogen test method will become a world standard for gastric cancer prevention in the near future. We also hope that, in other countries (especially in developing countries, which have high incidences of gastric cancer), as well as in Japan, there will be improvements in endoscopic skills in diagnosing early gastric cancers with subtle mucosal changes.

Acknowledgments This work was supported in part by a Grant-in-Aid for Research from the Ministry of Health, Labour, and Welfare, Japan (H16-025).

\section{References}

1. Huang SC, Miki K, Sano J, Ichinose M, Kawamura N, Oka H, et al. Pepsinogens I and II in gastric cancer: An immunohistochemical study using monoclonal antibodies. Jpn J Cancer Res 1988; 79:1139-46.

2. Oshima A, Hirata N, Ubukata T, Umeda K, Fujimoto I. Evaluation of a mass screening program for stomach cancer with a casecontrol study design. Int J Cancer 1986;38:829-33.

3. Fukao A, Tsubono Y, Tsuji I, Hisamichi S, Sugahara N, Takano A. The evaluation of screening for gastric cancer in Miyagi Prefecture, Japan: a population-based case-control study. Int J Cancer 1995;60:45-8.

4. Miki K, Ichinose M, Shimizu A, Huang SC, Oka H, Furihata C, et al. Serum pepsinogens as a screening test of extensive chronic gastritis. Gastroenterol Jpn 1987;22:133-41.

5. Miki K, Ichinose M, Ishikawa KB, Yahagi N, Matsushima M, Kakei N, et al. Clinical application of serum pepsinogen I and II levels for mass screening to detect gastric cancer. Jpn J Cancer Res 1993;84:1086-90.

6. Ichinose M, Yahagi N, Oka M, Ikeda H, Miki K, Omata M. Screening for gastric cancer in Japan. In: Wu GY, Aziz K, Editors. Cancer screening. A practical guide for physicians. Potawa: Humana Press; 2001. p. 87-102.

7. Miki K, Morita M, Sasajima M, Hoshina R, Kanda E, Urita Y. Usefulness of gastric cancer screening using the serum pepsinogen test method. Am J Gastroenterol 2003; 98:735-9.

8. Shiga T, Nishizawa M, Hayashi G. Comparison between the serum pepsinogen test method and the conventional photofluorography. A randomized controlled study. In: Miki K, editor. Pepsinogen test method. Tokyo: Igaku-shoin; 1998. p. 56-62 (in Japanese).
9. Miki K, Ichinose M, Kakei N, Yahagi N, Matsushima M, Tsukada $\mathrm{S}$, et al. The clinical application of the serum pepsinogen I and II levels as a mass screening method for gastric cancer. In: Takahashi K, editor. Aspartic proteinases: structure, function, biology and biomedical implications. New York: Plenum Press; 1995. p. 139-43.

10. Kikuchi S, Wada O, Miki K, Nakajima T, Nishi T, Kobayashi O, et al. Serum pepsinogen as a new marker for gastric carcinoma among young adults. Cancer 1994;73:2695-702.

11. Kitahara F, Kobayashi K, Sato T, Kojima Y, Araki T, Fujino MA. Accuracy of screening for gastric cancer using serum pepsinogen concentrations. Gut 1999;44:693-7.

12. Miki K, Ichinose M, Yahagi N, Suzuki T, Oka M, Shimizu Y, et al. Efficiency of gastric cancer screening system using serum pepsinogen test. In: Siewert JR, Roder JD, editors. Progress in gastric cancer research 1997. Bologna: Monduzzi Editore; 1997. p. 87-93.

13. Ohata H, Oka M, Yanaoka K, Shimizu Y, Mukoubayashi C, Mugitani K, et al. Gastric cancer screening of a high-risk population in Japan using serum pepsinogen and barium digital radiography. Cancer Sci 2005;96:713-20.

14. Samloff IM. Cellular localization of group I pepsinogens in human gastric mucosa by immunofluorescence. Gastroenterology 1971;61:185-8.

15. Samloff IM, Liebman WM. Cellular localization of the group II pepsinogens in human stomach and duodenum by immunofluorescence. Gastroenterology 1973;65:36-42.

16. Miki K, Pepsinogen. In: Miki K, editor. Gastric malignant tumor. Tokyo: Medical View; 2000. p. 78-84 (in Japanese).

17. Stemmermann GN, Samloff IM, Nomura A, Walsh JH. Serum pepsinogen I and gastrin in relation to extent and location of intestinal metaplasia in the surgically resected stomach. Dig Dis Sci 1980;25:680-7.

18. Miki K, Ichinose M, Kawamura N, Matsushima M, Ahmad HB, Kimura M, et al. The significance of low serum pepsinogen levels to detect stomach cancer associated with extensive chronic gastritis in Japanese subjects. Jpn J Cancer Res 1989;80:111-4.

19. Kodoi A, Yoshihara M, Sumii K, Haruma K, Kajiyama G. Serum pepsinogen in screening for gastric cancer. J Gastroenterol 1995;30:452-60.

20. Lauren P. The two histological main types of gastric carcinoma: diffuse and so-called intestinal type carcinoma. Acta Path Microbiol Scand 1965;64:31-49.

21. Correa P. Human gastric carcinogenesis: A multistep and multifactorial process - First American Cancer Society Award Lecture on Cancer Epidemiology and Prevention. Cancer Res 1992;52:6735-40.

22. Fukao A, Hisamichi S, Ohsato N, Fujino N, Endo N, Iha M. Correlation between the prevalence of gastritis and gastric cancer in Japan. Cancer Causes Control 1993;4:17-20.

23. Kabuto M, Imai H, Tsugane S, Watanabe S. Correlation between atrophic gastritis prevalence and gastric cancer mortality among middle-aged men in 5 areas in Japan. J Epidemiol 1993;3:35-9.

24. Namekata T, Miki K, Kimmey M, Fritsche T, Hughes D, Moore $\mathrm{D}$, et al. Chronic atrophic gastritis and Helicobacter pylori infection among Japanese Americans in Seattle. Am J Epidemiol 2000;151:820-30

25. Nomura AMY, Stemmermann GN, Samloff IM. Serum pepsinogen I as a predictor of stomach cancer. Ann Intern Med 1980;93:537-40.

26. Fahey MT, Hamada GS, Nishimoto IN, Kowalski LP, Lriya K, Gama-Podrigues JJ, et al. Ethnic differences in serum pepsinogen levels among Japanese and non-Japanese Brazilian gastric cancer patients and controls. Cancer Detect Prev 2000;24:564-71.

27. Palli D, Decarli A, Cipriani F, Forman D, Amadori D, Avellini C, et al. Plasma pepsinogens, nutrients and diet in areas of Italy at varying gastric cancer risk. Cancer Epidem Biomar Prev 1993;1: 45-50.

28. Parsonnet J, Samloff IM, Nelson LM, Orenreich N, Vogelman $\mathrm{JH}$, Freidman GD. Helicobacter pylori, pepsinogen, and risk for 
gastric adenocarcinoma. Cancer Epidem Biomar Prev 1993;2: $461-6$.

29. Stemmermann GN, Samloff IM, Nomura AMY, Heilburn LK. Serum pepsinogens I and II and stomach cancer. Clin Chim Acta 1987;163:191-8.

30. Matsusako K, Itoh M, Yokochi K, Miyamoto T, Joh T, Takeuchi $\mathrm{T}$, et al. An enzyme immunoassay for pepsinogen II: chronological changes in serum pepsinogen II concentrations. Clin Chim Acta 1987:169:239-47.

31. Ito M, Haruma K, Kaya S, Kamada T, Kim S, Sasaki A, et al. Serological comparison of serum pepsinogen and anti-parietal cell antibody levels between Japanese and German patients. Eur J Gastroenterol Hepatol 2002;14:123-7.

32. Samloff IM, Varis K, Ihamaki T, Siurala M, Rotter JI. Relationships among serum pepsinogen I, serum pepsinogen II, and gastric mucosal histology. A study in relatives of patients with pernicious anemia. Gastroenterology 1982;82:204-9.

33. Tamm A, Villako K, Harkonen M, Karonen SL. Serum pepsinogen I and the state of gastric mucosa in an Estonian population sample. Scand J Gastroenterol 1984;19:1091-4.

34. Ley C, Mohar A, Guarner J, Herrera-Goepfert R, Figueroa LS, Halperin D, et al. Screening markers for chronic atrophic gastritis in Chiapas, Mexico. Cancer Epidem Biomar Prev 2001;10:107-12.

35. Aromaa A, Kosunen TU, Knekt P, Maatela J, Teppo L, Heinonen OP, et al. Circulating anti-Helicobacter pylori immunoglobulin A antibodies and low serum pepsinogen I level are associated with increased risk of gastric cancer. Am J Epidemiol 1996;144:142-9.

36. Asaka M, Kimura T, Kudo M, Takeda H, Mitani S, Miyazaki T, et al. Relationship of Helicobacter pylori to serum pepsinogens in an asymptomatic Japanese population. Gastroenterology 1992; 102:760-6.

37. Webb PM, Hengels KJ, Moller H, Newell DG, Palli D, Elder JB, et al. The epidemiology of low serum pepsinogen A levels and an international association with gastric cancer rates. EUROGAST Study Group. Gastroenterology 1994;107:1335-44.

38. Yoshida S, Saito D. Gastric premalignancy and cancer screening in high-risk patients. Am J Gastroenterol 1996;91:839-43.

39. Dinis-Ribeiro M, Yamaki G, Miki K, Costa-Pereira A, Matsukawa M, Kurihara M. Meta-analysis on the validity of pepsinogen test for gastric carcinoma, dysplasia or chronic atrophic gastritis, J Med Screen 2004;11:141-7.

40. Ichinose M, Miki K, Furihata C, Kageyama T, Hayashi R, Niwa $\mathrm{H}$, et al. Radioimmunoassay of serum group I and group II pepsinogens in normal controls and patients with various disorders. Clin Chim Acta 1982;126:183-91.

41. Samloff IM. Pepsinogens I and II: Purification from gastric mucosa and radioimmunoassay in serum. Gastroenterology 1982; 82:26-33.

42. Huang SC, Miki K, Furihata C, Ichinose M, Shimizu A, Oka H. Enzyme-linked immunosorbent assays for serum pepsinogens I and II using monoclonal antibodies with data on peptic ulcer and gastric cancer. Clin Chim Acta 1988;175:37-50.

43. Konishi N, Matsumoto K, Hiasa Y, Kitahori Y, Hayashi I, Matsuda $\mathrm{H}$. Tissue and serum pepsinogen I and II in gastric cancer identified using immunohistochemistry and rapid ELISA. J Clin Pathol 1995;48:364-7.

44. Hattori Y, Tashiro H, Kawamoto T, Kodama Y. Sensitivity and specificity of mass screening for gastric cancer using the measurement of serum pepsinogens. Jpn J Cancer Res 1995;86:1210-5.

45. Miki K, editor. Pepsinogen handbook. Tokyo: Medical View; 2001. (Includes 17 papers in Japanese).

46. Bodger K, Wyatt JI, Heatley RV. Serological screening before endoscopy: The value of Helicobacter pylori serology, serum recognition of the CagA and VacA proteins, and pepsinogen I. Scand J Gastroenterol 1999;34:856-63.

47. Chang FY, Lai KH, Wang TF, Lee SD, Tsai YT, Tsay SH. Location and type of gastric carcinoma in relation to pepsinogen I level in blood. Scand J Gastroenterol 1992;27:884-8.
48. Zhang L, Blot WJ, You WC, Chang YS, Kneller RW, Jin ML, et al. Helicobacter pylori antibodies in relation to precancerous gastric lesions in a high-risk Chinese population. Cancer Epid Biomar Prev 1996;5:627-30.

49. Knight T, Wyatt J, Wilson A, Greaves S, Newell D, Hengels K, et al. Helicobacter pylori gastritis and serum pepsinogen levels in a healthy population: development of a biomarker strategy for gastric atrophy in high-risk groups. Br J Cancer 1996;73:81924.

50. Inoue M, Kobayashi S, Matsuura A, Hamajima N, Tajima K, Tominaga S. Agreement of endoscopic findings and serum pepsinogen levels as an indicator of atrophic gastritis. Cancer Epidem Biomar Prev 1998;7:261-3.

51. Sitas F, Smallwood R, Jewell D, Millard PR, Newell DG, Meuwissen SG, et al. Serum anti-Helicobacter pylori IgG antibodies and pepsinogens $\mathrm{A}$ and $\mathrm{C}$ as serological makers of chronic atrophic gastritis. Cancer Epidem Biomar Prev 1993;2:119-23.

52. Oksanen A, Sipponen P, Miettinen A, Sarna S, Rautelin H. Evaluation of blood tests to predict normal gastric mucosa. Scand J Gastroenterol 2000;35:791-5.

53. Kekki M, Samloff IM, Varis K, Ihamäki T. Serum pepsinogen I and serum gastrin in the screening of severe atrophic corpus gastritis. Scand J Gastroenterol 1991;186:109-16.

54. Varis K, Kekki M, Harkonen M, Sipponen P, Samloff IM. Serum pepsinogen I and serum gastrin in the screening of atrophic pangastritis with high risk of gastric cancer. Scand J Gastroenterol 1991;186:117-23.

55. Mardh E, Mardh S, Mardh B, Borch K. Diagnosis of gastritis by means of a combination of serological analyses. Clin Chim Acta 2002;320:17-27.

56. Miki K, Ichinose M. Serum pepsinogen I level in patients with stomach cancer: its value and limitation in clinical use. Gan To Kagaku Ryoho 1989; 16:1122-8 (in Japanese).

57. Fukunaga H, Morita K, Otsuka N, Morita R. Fundamental and clinical study for pepsinogen I and II RIABEAD Kit. Igaku-ToYakugaku (J Med Pharm Sci) 1989;21:905-14 (in Japanese).

58. Miki K. Mass screening of stomach neoplasms by serum pepsinogen analysis. Nippon Naika Gakkai Zasshi 1992;81:654-9 (in Japanese).

59. Kimura Y, Fujii T, Hamamoto K, Miyagawa N, Tsuda K, Tanada $\mathrm{S}$. Evaluation of serum pepsinogen I and II of patients with gastric cancer. Kaku Igaku 1999;26:1127-33 (in Japanese).

60. Yamaki G, Shiga Y, Nagahama R, Nakashima T, Nomoto K, Nakaya H. Pepsinogen test. Stomach and Intestine 2001; 36:1591-7 (in Japanese with English abstract).

61. Dinis-Ribeiro M, Costa-Pereira A, Lopes C, Barbosa J, Guilherme M, Moreira-Dias L, et al. Is pepsinogen test valid for the diagnosis of gastric dysplasia and adenocarcinoma? Gut 2002;51(Suppl. III):A 185.

62. You WC, Blot WJ, Zhang L, Kneller RW, Li JY, Lin ML, et al. Serum pepsinogens in relation to precancerous gastric lesions in a population at high risk for gastric cancer. Cancer Epidem Biomar Prev 1993;2:113-7.

63. Kikuchi S, Inaba Y, Wada O, Miki K, Tenjin H, Kaneko E, et al. The association of smoking and drinking habits with serum pepsinogens. Int J Epidemiol 1995;24:346-53.

64. Wagner S, Haruma K, Gladziwa U, Soudah B, Gebel M, Bleck J, et al. Helicobacter pylori infection and serum pepsinogen A, pepsinogen $\mathrm{C}$, and gastrin in gastritis and peptic ulcer: Significance of inflammation and effect of bacterial eradication. Am J Gastroenterol 1994;89:1211-8.

65. Ogihara A, Kikuchi S, Hasegawa A, Kurosawa M, Miki K, et al. Relationship between Helicobacter pylori infection and smoking and drinking habits. J Gastroenterol Hepatol 2000;15:271-6.

66. Hunter FM, Correa P, Fontham E, Ruiz B, Sobhan M, Samloff IM. Serum pepsinogens as markers of response to therapy for Helicobacter pylori gastritis. Dig Dis Sci 1993;38:2081-6.

67. Biasco G, Paganelli GM, Vaira D, Holton J, Febo GDi, Brillanti $\mathrm{S}$, et al. Serum pepsinogen I and II concentrations and IgG anti- 
body to Helicobacter pylori in dyspeptic patients. J Clin Pathol 1993;46:826-8.

68. Webb PM, Crabtree JE, Forman D, and The Eurogast Study Group. Gastric cancer, cytotoxin-associated gene A-positive Helicobacter pylori, and serum pepsinogens: An international study. Gastroenterology 1999;116:269-76.

69. Schlemper RJ, van der Werf SD, Vandenbroucke JP, Biemond I, Lamers CB. Seroepidemiology of gastritis in Japanese and Dutch working populations: evidence for the development of atrophic gastritis that is not related to Helicobacter pylori. Gut 1995;37: 199-204.

70. Goedhard JG, Biemond I, Gilliams JP, Pals G, Kreuning J. Serum pepsinogen I levels: assessment of gastric acid secretion? Pepsinogens in man: clinical and genetic advances, Prog Clin Biol Res 1985;173:139-46.

71. Kato I, Miki K, Muñoz N, Vivas JH, Lopez G, Peraza S, et al. Determinants of plasma pepsinogen levels in population at high risk for stomach cancer in Venezuela. Int $\mathrm{J}$ Cancer 1995;62:512-8.

72. Yoshihara M, Sumii K, Haruma K, Kiyohira K, Hattori N, Kitadai $\mathrm{Y}$, et al. Correlation of ratio of serum pepsinogen I and II with prevalence of gastric cancer and adenoma in Japanese subjects. Am J Gastroenterol 1998;93:1090-6.

73. Varis K, Taylor PR, Sipponen P, Samloff IM, Heinonen OP, Albanes D, et al. Gastric cancer and premalignant lesions in atrophic gastritis: a controlled trial on the effect of supplementation with alpha-tocopherol and beta-carotene. Scand J Gastroenterol 1998;33:294-300.

74. Wu M-S, Lee W-C, Lin J-T, Wang H-P, Wang T-H, Chen C-J. A novel tree-structured analysis for non-invasive diagnosis of gastric adenocarcinoma. Anticancer Res 1995;15:2739-43.

75. Farinati F, Di Mario F, Plebani M, Cielo R, Fanton MC, Valiante F, et al. Pepsinogen A/pepsinogen $\mathrm{C}$ or pepsinogen A multiplied by gastrin in the diagnosis of gastric cancer? Ital J Gastroenterol 1991;223:194-6.

76. Goldschmiedt M, Barnett CC, Schwarz BE, Karnes WE, Redfern JS, Feldman M. Effect of age on gastric acid secretion and serum gastrin concentrations in healthy men and women. Gastroenterology 1991;101:977-90.

77. Serrono MT, Lanas Al, Lorente S, Sainz R. Cytokine effects on pepsinogen secretion from human peptic cells. Gut 1997;40:42-8.

78. Lorente S, Doiz O, Trinidad Serrano M, Castillo J, Lanas A. Helicobacter pylori stimulates pepsinogen secretion from isolated human peptic cells. Gut 2002;50:13-8.

79. Fukuda H, Saito D, Hayashi S, Hisai H, Ono H, Yoshida S, et al. Helicobacter pylori infection, serum pepsinogen level and gastric cancer: A case-control study in Japan. Jpn J Cancer Res 1995; 86:64-71.

80. Varis K, Sipponen P, Laxén F, Samloff IM, Huttunen JK, Taylor $\mathrm{PR}$, et al. Implications of serum pepsinogen I in early endoscopic diagnosis of gastric cancer and dyplasia. Scand J Gastroenterol 2000:35:950-6.

81. Kikuchi S, Kurosawa M, Sakiyama T, Tenjin H, Miki K, Wada O, et al. Long-term effect of Helicobacter pylori infection on serum pepsinogens. Jpn J Cancer Res 2000;91:471-6.
82. Plummer M, Vivas J, Fauchere JL, Giudice GD, Pẽa AS, Ponzetto A, et al. Helicobacter pylori and stomach cancer: A case-control study in Venezuela. Cancer Epidem Biomar Prev 2000;9:961-5.

83. Ohata H, Kitauchi S, Yoshimura N, Mugitani K, Iwane M, Nakamura $\mathrm{H}$, et al. Progression of chronic atrophic gastritis associated with Helicobacter pylori infection increases risk of gastric cancer. Int J Cancer 2004;109:138-43.

84. Watabe H, Mitsushima T, Yamaji Y, Okamoto M, Wada R, Kokubo T, et al. Predicting the development of gastric cancer from combining Helicobacter pylori antibodies and serum pepsinogen status: a prospective endoscopic cohort study. Gut 2005; 54:764-8

85. Fujishiro M, Yahagi N, Kakushima N, Kodashima S, Nakamura M, Kobayashi K, et al. Early detection of asymptomatic gastric cancers using serum pepsinogen levels to indicate endoscopic submucosal dissection for better quality of life. Proceeding of $6^{\text {th }}$ International Gastric Cancer Congress. Yokohama 2005;145-50.

86. Sasajima M, Hoshina R, Miki K. Annual reports (1997-2000) of the Research Committee for the Study of Gastric Cancer Screening System Using the Serum Pepsinogen. Clin Gastroenterol 2002;17:1555-68 (in Japanese with English abstract).

87. Tsubono Y, Hisamichi S. Screening for gastric cancer in Japan. Gastric Cancer 2000;3:9-18.

88. Miki K. Annual report 2004 of the Research Committee of the Study of High Risk Strategy of Gastric Cancer Screening, supported by a Grant-in-Aid for the Research from the Ministry of Health, Labour and Welfare, Japan. Tokyo; 2005(April). p. 1-288 (in Japanese).

89. Muto M, Saito Y, Koike T, Miki K. A case of gastric cancer with high pepsinogen II levels in both serum and ascites. Dig Endosc 2000;12:42-5.

90. Ozasa K, Kurata JH, Higashi A, Hayashi K, Inokuchi H, Miki K, et al. Helicobacter pylori infection and atrophic gastritis. A nested case-control study in a rural town in Japan. Dig Dis Sci 1999; 44:253-6.

91. Watanabe Y, Kurata JH, Mizuno S, Mukai M, Inokuchi H, Miki $\mathrm{K}$, et al. Helicobacter pylori infection and gastric cancer. A nested case-control study in a rural area of Japan. Dig Dis Sci 1997;42:1383-7.

92. Asaka M, Kimura T, Kato M, Kudo M, Miki K, Ogoshi K,et al. Possible role of Helicobacter pylori infection in early gastric cancer development. Cancer 1994;73:2691-4.

93. Asaka M, Kato M, Kudo M, Katagiri M, Nishikawa K, Yoshida J, et al. Relationship between Helicobacter pylori infection, atrophic gastritis and gastric carcinoma in a Japanese population. Eur J Gastroenterol Hepatol 1995;s7-10.

94. Nomura A M Y,Klonel LN, Miki K, Stemmermann GN, Wilkens LR, Goodman MT, et al. Helicobacter pylori, pepsinogen and gastric adenocarcinoma in Hawaii. J Infect Dis 2005;191:2075-81.

95. Miki K, Urita Y, Nomura AMY, Kolonel LN, Stemmermann GN, Wilkens LR, et al. The relationship between Helicobacter pylori, pepsinogen, and gastric adenocarcinoma. Gut 2005;54 (Suppl. VII):A 70.

96. Hatakeyama M. Oncogenic mechanisms of the Helicobacter pylori CagA protein. Nature Rev Cancer 2004;4:688-94. 